\title{
Combining Fluorescence Microscopy and Flux Experiments for Visualizing the Mechanism of BSA Biofouling
}

\author{
Charles Widing ${ }^{1}$, Nathan Ruffle-Deignan ${ }^{1}$, and Elana Stennett ${ }^{1}$ \\ ${ }^{1}$ Hobart and William Smith Colleges
}

July 30,2020

\begin{abstract}
Flux experiments and fluorescence microscopy were combined and optimized to visualize the membrane surface during biofouling of two mixed cellulose ester membranes. Using flux measurements, the fouling by bovine serum albumin (BSA) was measured in the presence of 1 to $12 \%$ labeled BSA. By fitting the relative flux decays to an exponential decay for statistical analysis, the dye in this range of labeled protein was found to not affect the fouling nature of the protein. A $2.5 \%$ or $5 \%$ labeled protein sample was determined to be the best percent labeled protein for fluorescence imaging the membrane because the beginning of cake formation was observed within 25 min of experimental time. Finally, by fitting the flux data to four different biofouling mechanism equations, we conclude that both membranes, though at different rates, have BSA depositing inside the membrane pores restricting the flow eventually leading to cake formation. The combination of the two techniques allows for further insight into the biofouling mechanism of BSA, and this method can be applied to other biological molecules.
\end{abstract}

\section{Hosted file}

MainText.pdf available at https://authorea.com/users/347402/articles/473112-combiningfluorescence-microscopy-and-flux-experiments-for-visualizing-the-mechanism-of-bsabiofouling

\section{Hosted file}

Figures.docx available at https://authorea.com/users/347402/articles/473112-combiningfluorescence-microscopy-and-flux-experiments-for-visualizing-the-mechanism-of-bsa-

biofouling 